\title{
Comparison of saccharification and fermentation of steam exploded rice straw and rice husk
}

Ian P. Wood ${ }^{1}$, Huong-Giang Cao ${ }^{2}$, Long Tran², Nicola Cook ${ }^{3}$, Peter Ryden ${ }^{1}$, David R. Wilson', Graham K. Moates ${ }^{1}$, Samuel R. A. Collins ${ }^{1}$, Adam Elliston ${ }^{1}$ and Keith W. Waldron ${ }^{* *}$

\begin{abstract}
Background: Rice cultivation produces two waste streams, straw and husk, which could be exploited more effectively. Chemical pretreatment studies using rice residues have largely focussed on straw exploitation alone, and often at low substrate concentrations. Moreover, it is currently not known how rice husk, the more recalcitrant residue, responds to steam explosion without the addition of chemicals.

Results: The aim of this study has been to systematically compare the effects of steam explosion severity on the enzymatic saccharification and simultaneous saccharification and fermentation of rice straw and husk produced from a variety widely grown in Vietnam (Oryza sativa, cv. KhangDan18). Rice straw and husk were steam exploded (180-230 ${ }^{\circ} \mathrm{C}$ for $10 \mathrm{~min}$ ) into hot water and washed to remove fermentation inhibitors. In both cases, pretreatment at $210^{\circ} \mathrm{C}$ and above removed most of the noncellulosic sugars. Prolonged saccharification at high cellulase doses showed that rice straw could be saccharified most effectively after steam explosion at $210^{\circ} \mathrm{C}$ for $10 \mathrm{~min}$. In contrast, rice husk required more severe pretreatment conditions $\left(220^{\circ} \mathrm{C}\right.$ for $10 \mathrm{~min}$ ), and achieved a much lower yield ( $75 \%$ ), even at optimal conditions. Rice husk also required a higher cellulase dose for optimal saccharification (10 instead of $6 \mathrm{FPU} / \mathrm{g}$ DM). Hemicellulase addition failed to improve saccharification. Small pilot scale saccharification at $20 \%(\mathrm{w} / \mathrm{v})$ substrate loading in a $10 \mathrm{~L}$ high torque bioreactor resulted in similarly high glucose yields for straw (reaching $9 \% \mathrm{w} / \mathrm{v}$ ), but much less for husk. Simultaneous saccharification and fermentation under optimal pretreatment and saccharification conditions showed similar trends, but the ethanol yield from the rice husk was less than $40 \%$ of the theoretical yield.

Conclusions: Despite having similar carbohydrate compositions, pretreated rice husk is much less amenable to saccharification than pretreated rice straw. This is likely to attenuate its use as a biorefinery feedstock unless improvements can be made either in the feedstock through breeding and/or modern biotechnology, or in the pretreatment through the employment of improved or alternative technologies. Physiological differences in the overall chemistry or structure may provide clues to the nature of lignocellulosic recalcitrance.
\end{abstract}

Keywords: Bioethanol, Biomass, Saccharification, Fermentation, Rice straw, Rice husk, Steam explosion, Pretreatment

\section{Background}

Rice is the third most widely grown cereal crop in the world after maize and wheat. It is the staple food and a

\footnotetext{
*Correspondence: keith.waldron@ifr.ac.uk

${ }^{1}$ The Biorefinery Centre, Institute of Food Research, Norwich Research Park, Colney, Norwich NR4 7UA, UK

Full list of author information is available at the end of the article
}

considerable source of income for many tropical nations. Very large quantities of agricultural lignocellulosic residues are generated from rice cultivation. Annually, paddy rice cultivation produces over 660 million tonnes of rice, along with over 800 million dry tonnes of agricultural residues (mostly straw) including over 113 million tonnes of rice husks (hulls) [1, 2]. provided you give appropriate credit to the original author(s) and the source, provide a link to the Creative Commons license, and indicate if changes were made. The Creative Commons Public Domain Dedication waiver (http://creativecommons.org/ publicdomain/zero/1.0/) applies to the data made available in this article, unless otherwise stated. 
Vietnam is a major rice grower and produces over 60 million tonnes of rice straw and husks every year. The bulk of this biomass is disposed of by burning, resulting in substantial emissions of black carbon, methane and the generation of tropospheric ozone leading to high levels of air pollution [3]. This has negative impacts on air quality and human health, reduces crop productivity and contributes to global warming $[4,5]$. Decreasing emissions from burning agricultural waste, amongst other measures, should be adopted as a priority measure by the international community if we are to meet the proposed $2{ }^{\circ} \mathrm{C}$ target for limiting anthropogenic global temperature increases. Other potential disposal methods, such as incorporation into wet soil, are also responsible for increased methane emissions [6]. Hence, there is great interest in developing approaches to exploit the energy potential of such biomass, for example, through conversion to energy or to biofuels.

There have been a number of studies on the pretreatment, enzymatic saccharification and in some cases simultaneous saccharification and fermentation (SSF) of rice straw for the production of ethanol fuel. A range of pretreatments have been assessed, including steam explosion $[7,8]$, steam explosion and biological pretreatment [9], alkaline pulping [10], microwave alkali heating [3] organosolvent pretreatments [11] and fine milling [12]. There have been comparatively fewer studies on rice husk which have included investigations into microwave alkali heating [3], hydrogen peroxide treatments [13] and wet air oxidation [14]. Very few studies have used one of the most promising pretreatment technologies, steam explosion, for rice husks in relation to enzymatic saccharification with or without fermentation [15].

At a lab-scale, strong alkali and alkali-peroxide pretreatments typically perform well $[15,16]$. However, commercial use of alkali at the levels used in the laboratory, usually at between $10 \%$ [16] and $100 \%$ [17] weight equivalent of the biomass, would require expensive waste water remediation to avoid pollution. Steam explosion, on the other hand, can be carried out without any added chemicals. Moreover, heat used for pretreatment can be recovered and used for downstream processes [18]. In addition, published studies on rice straw and husk that have been carried out in the laboratory are typically conducted at a very small scale $<100-300 \mathrm{~mL}$, and substrate concentrations generally $<10 \%(\mathrm{w} / \mathrm{v})$. This potentially limits the relevance of these processes, when scaled up to industrial scales. Under commercial conditions, higher substrate concentrations would almost certainly be needed to produce suitable ethanol concentrations.

In the light of these discrepancies, and because studies on alkaline pretreatments suggest that rice husk is more difficult to saccharify effectively than rice straw [3,
$15,19]$, the aim of this research has been to carry out a carefully controlled comparative study of the effect of steam explosion pretreatment on enzymatic saccharification, and simultaneous saccharification and fermentation of rice straw and rice husk. We used a cultivar widely grown in North East Vietnam to evaluate saccharification of both substrates at small pilot scale. This has enabled us to identify key differences in processing capabilities between the two tissue types, and to demonstrate that at small pilot scale, steam exploded rice straw can be saccharified with minimal enzymes to produce industrially useful glucose concentrations.

\section{Methods}

\section{Aim of the study and sourcing of biomass}

The aim of this research has been to compare the effects of steam explosion pretreatment on enzymatic saccharification, and simultaneous saccharification and fermentation of rice straw and rice husk. Field grown rice (Oryza sativa, cv. KhangDan18) straw and husk was harvested at maturity in spring 2012 at $\mathrm{Ba} \mathrm{Vi}$, Hanoi, Vietnam. The biomass was fumigated and then air-dried under ambient conditions (approx. $34{ }^{\circ} \mathrm{C}, 84 \% \mathrm{RH}$ ) at the Agricultural Genetics Institute (Hanoi, Vietnam). Before steam explosion pretreatment, the moisture content of the straw was determined to be $9.01 \%$ and the husk $9.98 \%(w / w)$.

\section{Steam explosion of rice straw and husk}

Both rice straw and husk were steam exploded into hot water $\left(70-80{ }^{\circ} \mathrm{C}\right)$ using a Cambi ${ }^{\mathrm{TM}}$ Steam Explosion facility with a $35 \mathrm{~L}$ reactor (Cambi AS, Asker, Norway). The rice straw was cut into lengths of $2-3 \mathrm{~cm}$ prior to loading the reactor. No size reduction was needed for the husk. The reactor was charged with $500 \mathrm{~g}$ of feedstock, sealed and heated with steam to the desired temperature (180$230{ }^{\circ} \mathrm{C}$ ) at which it was retained for $10 \mathrm{~min}$. After this time, the contents of the heating chamber were exploded into $3.5 \mathrm{~L}$ of hot water. The pretreated slurry was collected and fractionated into solid and liquid phases by centrifuging through a $100 \mu \mathrm{m}$ nylon mesh. The insoluble residue was washed extensively to remove any watersoluble material. Both fractions were quantified, and samples stored at $-40{ }^{\circ} \mathrm{C}$. Portions of this material were freeze-dried for carbohydrate analysis.

\section{Carbohydrate composition of solids}

Freeze-dried solids were acid hydrolysed $(72 \%(\mathrm{w} / \mathrm{w})$ $\mathrm{H}_{2} \mathrm{SO}_{4}, 3 \mathrm{~h}$, RT followed by dilution to $98 \mathrm{~g} / \mathrm{L} \mathrm{H}_{2} \mathrm{SO}_{4}$, and heating for $2.5 \mathrm{~h}, 100{ }^{\circ} \mathrm{C}$ ) to convert polymeric sugars into their monomeric constituents [20]. The hydrolysed samples were cooled on ice $(>10 \mathrm{~min})$ and then centrifuged ( $2500 \mathrm{rpm}, 2 \mathrm{~min}$ ). To a $1 \mathrm{~mL}$ aliquot from each hydrolysed sample $100 \mu \mathrm{L}$ ribose internal standard 
(30 mg/mL) was added. Samples were neutralised with $\mathrm{CaCO}_{3}(2.5 \mathrm{~mL}, 2 \mathrm{~mol} / \mathrm{L})$. The precipitated salt was removed by centrifugation (3000 rpm, $10 \mathrm{~min})$. Filter plates (AcroPrep ${ }^{\mathrm{TM}} 0.2 \mu \mathrm{m}$ GHP Membrane 96 Well Filter Plates, VWR International Ltd, Lutterworth, UK) were used to filter portions of each sample $(1 \mathrm{~mL})$ prior to HPLC by centrifugation at $500 \mathrm{rpm}$ for $10 \mathrm{~min}$. Deep well collection plates were sealed with pierceable lids (Starlab (UK) Ltd, Milton Keynes, UK) and loaded directly onto Series 200 LC instrument (Perkin Elmer, Seer Green, UK) equipped with a refractive index detector and employing an Aminex HPX-87P carbohydrate analysis column (Bio-Rad Laboratories Ltd, Hemel Hempstead, UK) with matching guard columns.

\section{Small scale saccharification}

Small scale saccharification was carried out in $25 \mathrm{~mL}$ universal vials (Sterilin, Newport, Gwent, UK), hydrolysing $1 \mathrm{~g}$ DM equivalent of wet pretreated solid, made to $5 \%$ substrate concentration with sodium acetate/acetic acid buffer ( $8.2 \mathrm{~g} / \mathrm{L}, \mathrm{pH} 5.0)$. The buffer contained $0.01 \%(\mathrm{w} / \mathrm{v})$ thiomersal to prevent microbial contamination. Hydrolyses were conducted for $96 \mathrm{~h}$ at $50{ }^{\circ} \mathrm{C}$, under continuous agitation in a Thermoshake Incubating Orbital Shaker (Gerhardt, Königswinter, Germany) after adding an appropriate amount of cellulase. The two commercially available enzyme preparations used in this study were Cellic $^{\circledR}$ CTec2 assayed following Ghose [21] and Cellic ${ }^{\circledR}$ HTec2 (Novozymes, Bagsvaerd, Denmark). Hydrolysis reactions were terminated by heating the hydrolysate in sealed tubes $\left(100{ }^{\circ} \mathrm{C}, 10 \mathrm{~min}\right)$ after which the samples were cooled, centrifuged $\left(2000 \mathrm{rpm}, 2 \min 25^{\circ} \mathrm{C}\right)$ and the supernatants recovered for analysis.

\section{Small scale simultaneous saccharification and fermentations}

Small scale simultaneous saccharification and fermentation (SSF) was conducted in $30 \mathrm{~mL}$ wide-necked glass vials containing $1 \mathrm{~g}$ (DM equivalent) of wet pretreated solid, made up to $17.9 \mathrm{~mL}$ with yeast nitrogen base (Formedium, Hunstanton, UK) at $\mathrm{pH}$ 5.0. The bottles were then autoclaved $\left(121{ }^{\circ} \mathrm{C}, 15 \mathrm{~min}\right)$ to ensure sterility. The bottles were cooled to $25^{\circ} \mathrm{C}$, and $2 \mathrm{~mL}$ of yeast grown in Difco YM media (Fisher Scientific UK Ltd, Loughborough, UK), was added along with $100 \mu \mathrm{L}$ Cellic ${ }^{\circledR}$ CTec2 (Novozymes, Bagsvaerd, Denmark), 20 FPU/g substrate. The yeast inoculum used was a Saccharomyces cerevisiae strain-NCYC 2826-chosen from the National Collection of Yeast Cultures (UK), selected on the basis of its high ethanol tolerance $(15-20 \% \mathrm{v} / \mathrm{v})$. The inoculum had a viable cell count of $9.87 \times 10^{7}$ cells $/ \mathrm{mL}$. Bottles were incubated under continuous agitation $\left(120 \mathrm{~h}, 25^{\circ} \mathrm{C}\right)$ after which, a measured sample was boiled in gas tight screw cap tubes (Starlab Ltd, Milton Keynes, UK), centrifuged $(13,000 \mathrm{rpm}, 5 \mathrm{~min})$ and supernatant filtered through AcroPrep $^{\text {TM }} 0.2 \mu \mathrm{m}$ GHP Membrane 96 Well Filter Plates (VWR International Ltd, Lutterworth, UK) into a 96 deep well collection plate before analysis.

\section{Five litre pilot scale hydrolyses in high torque bioreactor}

Pilot scale hydrolyses (5 L) were conducted in a bespoke high torque bioreactor [22]. Digests were conducted at $20 \%(\mathrm{w} / \mathrm{v})$ substrate concentration, using $1 \mathrm{~kg} D W$ equivalent of steam exploded rice straw/husk suspended in sodium acetate/acetic acid buffer ( $4.1 \mathrm{~g} / \mathrm{L}, \mathrm{pH} 5.0$ ). The buffer and substrate were initially heated to $>85{ }^{\circ} \mathrm{C}$ for $10 \mathrm{~min}$ to minimise the possibility microbial contamination. The mixture was then cooled to $50{ }^{\circ} \mathrm{C}$ and an appropriate amount of Cellic ${ }^{\circledR} \mathrm{CTec} 2$ was addedthe optimum was either 6.49 or $10 \mathrm{FPU} / \mathrm{g}$ DM for straw and husk, respectively. The hydrolysate was agitated at $39 \mathrm{rpm}$ for 4 days, taking $100 \mathrm{~mL}$ samples of the digest every $24 \mathrm{~h}$. Each sample was heated in a sealed tube to $\left(100{ }^{\circ} \mathrm{C}, 10 \mathrm{~min}\right)$, centrifuged $(2000 \mathrm{rpm}, 2 \mathrm{~min})$ and the monomeric sugar composition determined.

\section{Quantification of hydrolysis and fermentation products}

The concentration of reducing sugars released from the substrates was quantified using a scaled dinitrosalicylic acid (DNS) method [23]. Glucose concentrations were quantified using a glucose-specific kit (GOPOD, Megazyme International Ireland, Bray, Ireland). Substrate and enzyme controls were included wherever necessary.

Terminated fermentations, after centrifugation and filtration through a $0.2 \mu \mathrm{m}$ filter, were loaded directly onto a Series 200 LC instrument (Perkin Elmer, Seer Green, UK) equipped with a refractive index detector. The analyses were carried out using an Aminex HPX-87P carbohydrate analysis column (Bio-Rad Laboratories Ltd, Hemel Hempstead, UK) with matching guard columns operating at $65{ }^{\circ} \mathrm{C}$ with ultrapure water as mobile phase at a flow rate of $0.6 \mathrm{~mL} / \mathrm{min}$ as described [22].

\section{Quantification of fermentation inhibitors}

Pretreatment-derived supernatants were recentrifuged $(2465 \times g)$ and $200 \mu \mathrm{L}$ of the supernatant syringe filtered into vials $(0.2 \mu \mathrm{m}$, Whatman International Ltd, Maidstone, UK). The concentration of the fermentation inhibitors 2-furfuraldehyde (2-FA), 5-Hydroxymethylfurfural (5-HMF) and the organic acids (formic and acetic acid) were analysed by HPLC using a Flexar LC instrument (PerkinElmer, Seer Green, Bucks., UK) equipped with refractive index and photo diode array detectors (reading at $210 \mathrm{~nm}$ wavelength) in series. The analyses were carried out using an Aminex HPX-87H carbohydrate analysis column (Bio-Rad Laboratories Ltd, Hemel 
Hempstead, UK) operating at $65{ }^{\circ} \mathrm{C}$ with $0.005 \mathrm{~mol} / \mathrm{L}$ $\mathrm{H}_{2} \mathrm{SO}_{4}$ (Sigma-Aldrich) as mobile phase at a flow rate of $0.6 \mathrm{~mL} / \mathrm{min}$.

\section{Statistical analysis}

Unless otherwise stated, all analyses were performed in triplicate and presented as means and standard deviations. Curve fitting was conducted in Genstat v.18 (VSN International).

\section{Results and discussion}

Effect of pretreatment on the recovery and chemical composition of rice straw and husk

Rice straw and husk samples were pretreated by steam explosion at temperatures of between 180 and $230{ }^{\circ} \mathrm{C}$ after which they were exploded into hot water. At the lower intensities $\left(180-190{ }^{\circ} \mathrm{C}\right.$ for $\left.10 \mathrm{~min}\right)$, the steam exploded materials retained considerable structure, and were slightly darkened in colour compared with the control. At higher severities, the biomass became much darker in colour and lost most of its structure, with an increase in fine particulate matter. The yields of insoluble dry matter recovered are shown in Fig. 1. The decrease in insoluble dry matter at higher severities was due to a combination of solubilisation of cell wall components (predominantly hemicelluloses, lignin and salts), hydrolysis, breakdown and some volatilisation of wall components. At the highest severities, additional losses of fine particulate matter through the recovery mesh and the loss of some insoluble solids from the cyclone in the steam exploder were more likely.

The main cell wall sugars present in the raw and pretreated straw and husk residues are shown in Fig. 2. The

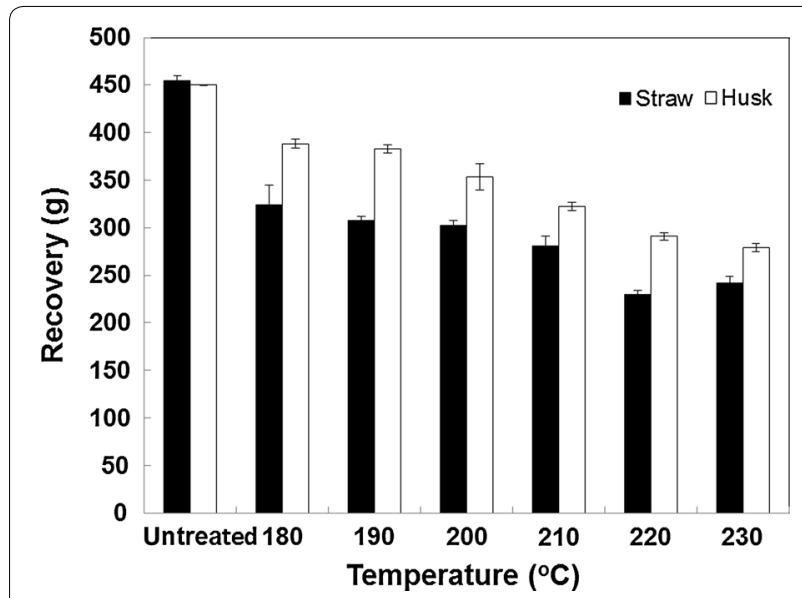

Fig. 1 Yield of rice straw and rice husk dry matter after steam explosion. Rice straw and rice husk were steam exploded into hot water after a residence time of $10 \mathrm{~min}$ at $180-230^{\circ} \mathrm{C}$. The residues were washed and aliquots freeze-dried

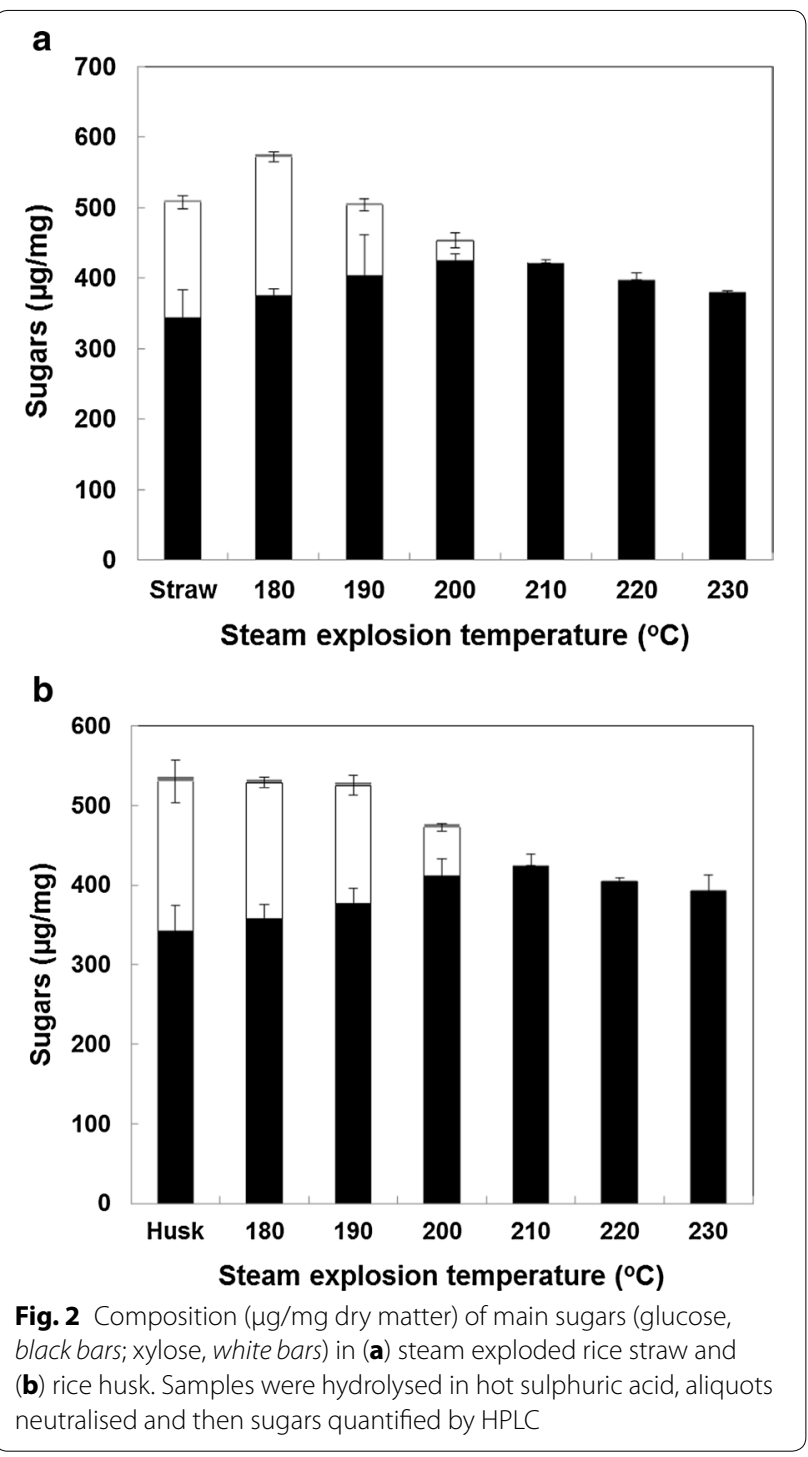

levels of cellulosic glucose and hemicellulosic xylose are similar to those reported previously for rice straw [3, 24, $25]$ and hulls $[3,13]$. The steam explosion pretreatment and washing reduced the levels of insoluble hemicellulosic xylose as severity increased. Xylose was completely removed by steam explosion at temperatures at or above $210{ }^{\circ} \mathrm{C}$. This is consistent with previous observations [7] and is similar to the effects of steam explosion on wheat straw [26]. Other neutral sugars such as arabinose and galactose were present at very low levels and are not shown. The loss of the hemicellulosic components and probably some of the lignin resulted in an increase in the proportions of (cellulosic) glucose. However, this peaked under treatment conditions of $200{ }^{\circ} \mathrm{C}$ for $10 \mathrm{~min}$ for rice straw, and $210{ }^{\circ} \mathrm{C}$ for $10 \mathrm{~min}$ for rice hull after which it declined, probably due to breakdown of some of 
the cellulose. The high-severity related loss of sugars also resulted in an increase in the levels of breakdown products (including fermentation inhibitors) recovered in the aqueous phase. These were measured by HPLC and the results highlight the production of formic acid, acetic acid, 5-HMF and 2-FA (Table 1). Interestingly, the rice straw and hull differed significantly in their production of breakdown products. At the low severities, more 5-HMF and 2-FA were released from the straw as compared with the hull. However, at the higher severities, this was reversed. The implications of this are discussed below.

\section{Enzymatic saccharification-impact of pretreatment}

Pretreated, insoluble straw and husk residues were subjected to an extended digestion in cellulase Cellic ${ }^{\circledR} \mathrm{CTec} 2$ at a loading of $10 \mathrm{FPU} / \mathrm{g}$ DM (circa $25 \mathrm{FPU} / \mathrm{g}$ cellulose) for $96 \mathrm{~h}$ at $50{ }^{\circ} \mathrm{C}$ whilst being continually agitated. The glucose released was measured using the specific GOPOD assay (see "Methods" section) and the results are shown in Fig. 3. At all severities, the glucose released from rice straw was of a greater yield compared with that from rice husk. This does not, however, reflect variation in the levels of cellulosic glucose present in the substrates (Fig. 2). The highest yields of glucose from straw were achieved after severities at or greater than $210{ }^{\circ} \mathrm{C}$ for $10 \mathrm{~min}$ (Fig. 3). Higher severities had no additional impact, and indeed suggested a (nonsignificant) reduction in yield, consistent with the slightly lower levels of substrate glucose shown in Fig. 2a. The results indicate that virtually all of the measurable glucose present in the pretreated straw was released under such conditions.

In comparison, the saccharification of rice husk was much less efficient. The maximum enzymatic release of glucose required a higher pretreatment severity $\left(220^{\circ} \mathrm{C}\right.$ for

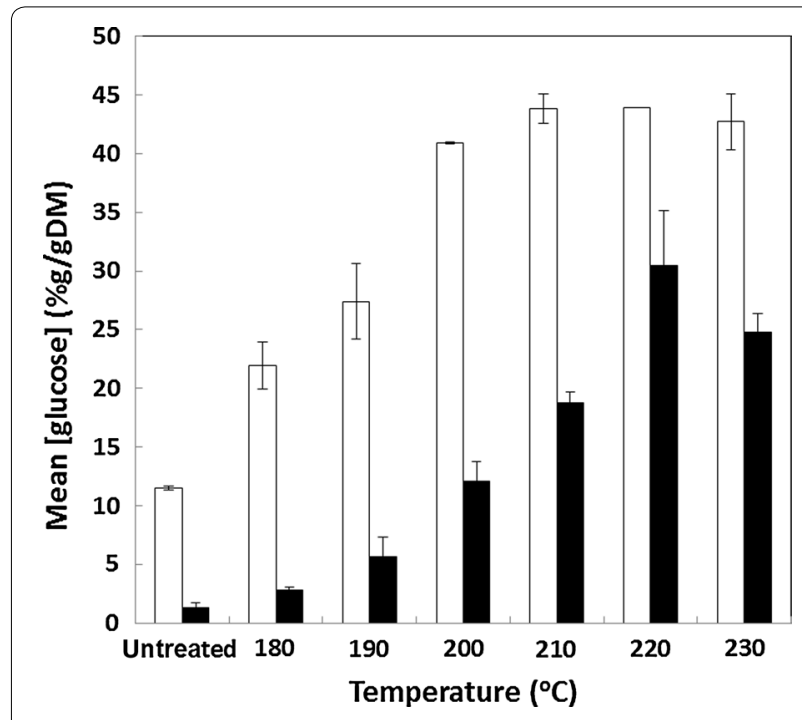

Fig. 3 Impact of pretreatment severity on saccharification (glucose release) of rice straw (white bars) and rice husk (black bars); $n=2$. Samples were digested whilst being agitated at a substrate concentration of $5 \%(\mathrm{w} / \mathrm{v})$ at $50^{\circ} \mathrm{C}$ for $96 \mathrm{~h}$ in cellulase (Cellic ${ }^{\circledR} \mathrm{CTec}$; circa $25 \mathrm{FPU} / \mathrm{g}$ cellulose)

Table 1 Quantity of organic acid held in the pretreatment liquor, expressed as $\mathrm{g}$ per $\mathbf{k g}$ of original straw

\begin{tabular}{|c|c|c|c|c|}
\hline Steam explosion temperature $\left({ }^{\circ} \mathrm{C}^{\mathrm{a}}\right)$ & Formic & Acetic & 5-HMF & 2-FA \\
\hline \multicolumn{5}{|l|}{180} \\
\hline Straw & $17.30 \pm 0.34$ & $11.76 \pm 0.25$ & $1.34 \pm 0.00$ & $1.80 \pm 0.14$ \\
\hline Husk & $3.57 \pm 0.05$ & $2.52 \pm 0.07$ & $0.51 \pm 0.05$ & $0.41 \pm 0.00$ \\
\hline \multicolumn{5}{|l|}{190} \\
\hline Straw & $16.56 \pm 0.05$ & $10.21 \pm 0.06$ & $1.21 \pm 0.04$ & $2.07 \pm 0.07$ \\
\hline Husk & $8.12 \pm 0.16$ & $8.06 \pm 0.06$ & $0.88 \pm 0.02$ & $2.19 \pm 0.00$ \\
\hline \multicolumn{5}{|l|}{200} \\
\hline Straw & $16.60 \pm 0.94$ & $9.37 \pm 0.66$ & $1.50 \pm 0.08$ & $1.43 \pm 0.08$ \\
\hline Husk & $6.96 \pm 0.41$ & $8.15 \pm 0.81$ & $1.18 \pm 0.05$ & $3.21 \pm 0.51$ \\
\hline \multicolumn{5}{|l|}{210} \\
\hline Straw & $15.05 \pm 0.30$ & $9.78 \pm 0.11$ & $1.30 \pm 0.04$ & $1.19 \pm 0.04$ \\
\hline Husk & $6.12 \pm 2.40$ & $8.24 \pm 2.57$ & $1.58 \pm 0.33$ & $2.69 \pm 0.78$ \\
\hline \multicolumn{5}{|l|}{220} \\
\hline Straw & $13.60 \pm 0.69$ & $8.26 \pm 0.41$ & $0.99 \pm 0.08$ & $0.75 \pm 0.03$ \\
\hline Husk & $6.87 \pm 0.03$ & $11.07 \pm 0.04$ & $2.58 \pm 0.00$ & $2.56 \pm 0.02$ \\
\hline \multicolumn{5}{|l|}{230} \\
\hline Straw & $1.81 \pm 0.09$ & $1.77 \pm 0.05$ & $0.35 \pm 0.00$ & $0.37 \pm 0.02$ \\
\hline Husk & N.D. & N.D. & N.D. & N.D. \\
\hline
\end{tabular}

a Residence time in all cases was $10 \mathrm{~min}$ 
$10 \mathrm{~min}$ ) and the extent of saccharification was even then only about $75 \%$ that of the straw. Increasing the severity to $230{ }^{\circ} \mathrm{C}$ for $10 \mathrm{~min}$ resulted in a significant reduction in glucose yield. In comparison, Pineros-Castro et al. [15] studied the effect of acid-catalysed steam explosion of rice husk on enzymatic saccharification. They impregnated the husks with $0.5 \%(\mathrm{w} / \mathrm{v})$ sulphuric acid and steam exploded at $190{ }^{\circ} \mathrm{C}$ for between 10 and $25 \mathrm{~min}$. After saccharification with high levels of cellulase $\left(\right.$ Celluclast $^{\circledR}$ at $15 \mathrm{FPU} / \mathrm{g})$, they achieved a maximum glucose yield of only $15 \%(w / w)$, which from the chemical composition of the initial starting material of $35 \%(\mathrm{w} / \mathrm{w})$ was less than half of the theoretical yield and much less than that achieved in this study. Cabrera et al. [19] compared the impact of alkaline and alkaline peroxide pretreatments at lower temperatures to enhance enzymatic hydrolysis of rice hulls and straw. They also employed a high enzyme loading (circa 20 FPU/g cellulose) for $72 \mathrm{~h}$ on pretreated and insoluble biomass and found that whilst they were able to achieve over $90 \%$ hydrolysis of reducing sugars from rice straw, rice hulls gave a yield of $77.5 \%$ which is similar to this study but necessitates the use of polluting alkali. Singh et al. [3] evaluated enzymatic saccharification of rice straw and hull after microwave alkali pretreatment. In that study, they produced enzymes in situ by incubating the pretreated residues with Aspergillus heteromorphus and monitored digestion and the release of reducing sugars. In pretreated rice straw, up to $35 \mathrm{mg} / \mathrm{g}$ sugars were released whilst in hull, this was limited to about $22 \mathrm{mg} / \mathrm{g}$. Hence, across all pretreatment conditions studied including this study on steam explosion, the cellulose from rice straw is much more readily hydrolysable than the cellulose from rice husk.

\section{Enzymatic saccharification-optimisation of enzyme loadings}

On the basis of the data above, material pretreated at 210 and $220^{\circ} \mathrm{C}$ was employed for the optimisation of enzyme loading. Pretreated material $(5 \% \mathrm{w} / \mathrm{v})$ was digested with cellulase (Cellic $\left.{ }^{\circledR} \mathrm{CTec} 2\right)$ for $96 \mathrm{~h}$ at $50{ }^{\circ} \mathrm{C}$ using a range of loadings after which the release of glucose was determined (Fig. 4). For pretreated rice straw $\left(210{ }^{\circ} \mathrm{C}\right.$, $10 \mathrm{~min}$ ), the minimum loading of cellulase required to obtain maximum glucose release was 7 FPU/g DM (circa $18 \mathrm{FPU} / \mathrm{g}$ cellulose). In contrast, the pretreated rice husk required a higher loading in excess of $10 \mathrm{FPU} / \mathrm{g} \mathrm{DM}$ (circa $25 \mathrm{FPU} / \mathrm{g}$ cellulose). Consistent with the results in Fig. 3, the maximum yield of glucose from rice husk was also much less than that of straw highlighting its relatively lower suitability as a substrate.

Novozymes Cellic ${ }^{\circledR}$ CTec2 can be augmented by a cocktail of accessory enzymes (Cellic ${ }^{\circledR}$ HTec2) which contains hemicellulose-degrading enzymes such as xylanases [27]. The addition of Cellic ${ }^{\circledR} \mathrm{HTec} 2$ on the

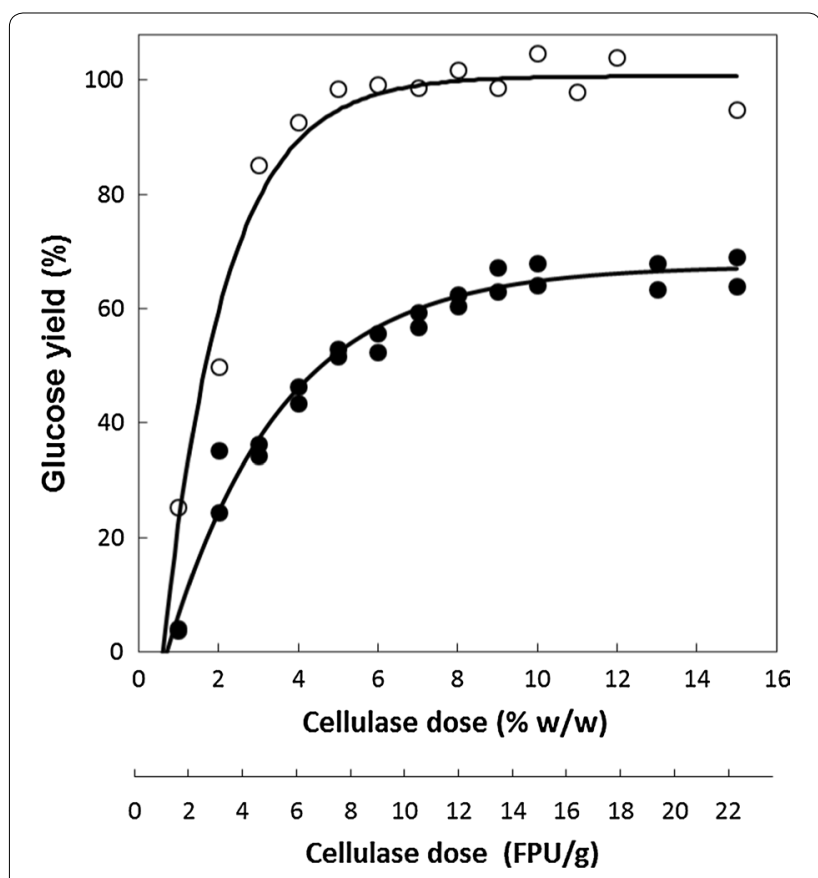

Fig. 4 Optimisation of enzyme loading for saccharification. Yields of glucose achieved when hydrolysing rice straw (circle) and husk (filled circle) steam exploded at optimum conditions (10 min at 210 and $220^{\circ} \mathrm{C}$, respectively). Glucose yields are expressed as a percentage of the maximum theoretical yield. Samples were digested whilst being agitated at a substrate concentration of $5 \%(\mathrm{w} / \mathrm{v})$ at $50{ }^{\circ} \mathrm{C}$ for $96 \mathrm{~h}$ in cellulase (Cellic ${ }^{\circledR}$ CTec2; between 0 and circa 22 FPU/g cellulose)

efficiency of saccharification of pretreated rice straw and husk was also evaluated by substituting Cellic ${ }^{\circledR}$ CTec2 with increasing levels of Cellic ${ }^{\circledR}$ HTec2. However, Cellic ${ }^{\circledR}$ HTec2 addition had no significant impact on the efficacy of Cellic ${ }^{\circledR} \mathrm{CTec} 2$ on saccharification (Additional file 1: Figure $\mathrm{S} 1 \mathrm{a}, \mathrm{b}$ ). This is consistent with the prior removal of any sterically inhibiting hemicelluloses by the steam explosion pretreatment and could have an economically beneficial impact on the overall cost of enzymes used in the process.

\section{Simultaneous saccharification and fermentation}

The potential for conversion of the cellulosic components of pretreated rice straw and husk to ethanol was also evaluated at small scale, under simultaneous saccharification and fermentation (SSF) conditions. Weighed aliquots of pretreated biomass ( $1 \mathrm{~g} \mathrm{DM}$, wet state) were made up to $5 \%(\mathrm{w} / \mathrm{v})$ in yeast nitrogen base, autoclaved, cooled to $25^{\circ} \mathrm{C}$, and inoculated with a high ethanol tolerance yeast strain and excess Cellic ${ }^{\circledR}$ CTec2 to $20 \mathrm{FPU} / \mathrm{g}$ DM. SSF was carried out at $25^{\circ} \mathrm{C}$ for $120 \mathrm{~h}$ after which the levels of ethanol in the supernatant were measured by HPLC. The results are shown in Fig. 5. The yield of ethanol from rice straw appears to be optimal in the material pretreated at 


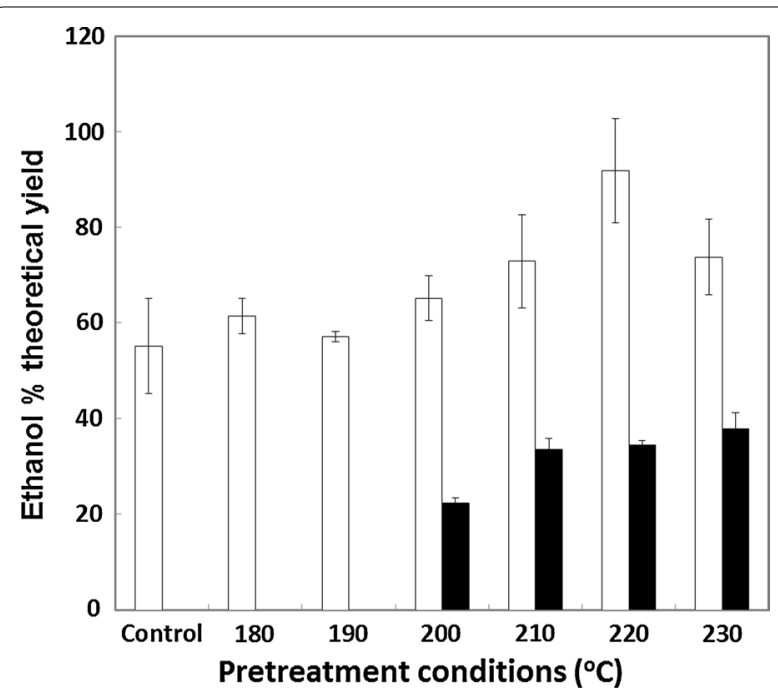

Fig. 5 Simultaneous saccharification and fermentation (SSF) of rice straw and rice husk for $96 \mathrm{~h}$ after steam explosion pretreatment at different severities. SSF was carried out with $5 \%(\mathrm{w} / \mathrm{V})$ substrate, cellulase (Cellic ${ }^{\circledR} \mathrm{CTec}$; circa 20 FPU/g dry matter) and yeast (NCYC 2826) at $25^{\circ} \mathrm{C}$ and $\mathrm{pH} 5$

$220{ }^{\circ} \mathrm{C}$, perhaps slightly higher than observed from saccharification alone $\left(210^{\circ} \mathrm{C}\right.$; Fig. 3).Thus, pretreatment in the range of $210-220^{\circ} \mathrm{C}$ enables quantitative conversion of cellulosic glucose to ethanol. This was not the case for rice husk which produced particularly low ethanol yields. Low severity pretreatment during the autoclave sterilisation process may explain why the untreated rice straw yielded higher ethanol yields than might be expected when compared with the saccharification data.

\section{Enzymatic saccharification-increasing the concentration of glucose released}

The bulk of academic studies on saccharification of lignocellulose predominantly involve low substrate concentrations to enable good mixing in suspension. To provide a comparison of straw and husk saccharification under more industrially relevant conditions, a small pilot scale study was performed at $10 \mathrm{~L}$ using a scalable high torque bioreactor developed previously [22, 28]. This enabled digests to be carried out at a high solids loadings of $20 \%$ $(\mathrm{w} / \mathrm{v})$ which would not have mixed effectively on a normal bench shaker incubator or stirrer due to the high viscosity. Bulk quantities of straw and husk were pretreated at the optimal conditions specified, and optimised Cellic ${ }^{\circledR}$ CTec2 enzyme loadings were used for rice straw (6.49 FPU/g DM) and husk (10 FPU/g DM). Samples were taken regularly over a $96 \mathrm{~h}$ period and analysed for the release of monomeric glucose. The results (Fig. 6) clearly show that at high substrate concentrations, the cellulose in pretreated rice straw can be quantitatively saccharified

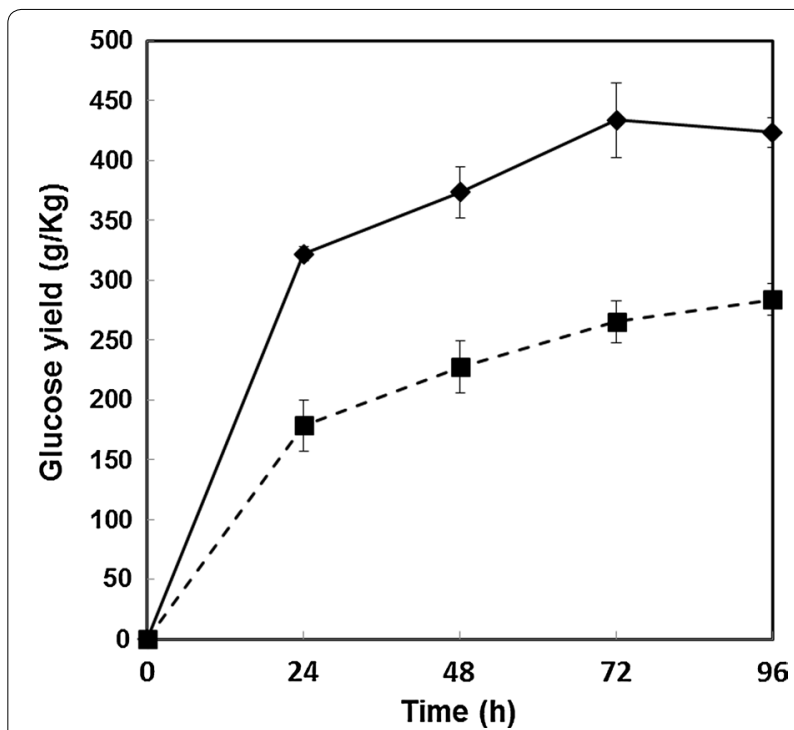

Fig. 6 Time course of glucose yields $(\mathrm{g} / \mathrm{kg}$ ) from pretreated straw and husk at small pilot scale (the glucose reached a concentration of $9 \% w / v) n=5$. Saccharification was conducted at $20 \%(w / v)$ substrate concentration, using $1 \mathrm{~kg}$ DW equivalent of steam exploded rice straw/husk ( $\mathrm{pH}$ 5.0). After a pasteurisation at $90^{\circ} \mathrm{C}$, the mixture was cooled to $50^{\circ} \mathrm{C}$ and Cellic ${ }^{\circledR} \mathrm{CTec} 2$ was added. The hydrolysate was agitated at $39 \mathrm{rpm}$ for 4 days, sampling every $24 \mathrm{~h}$

to glucose with a yield of approximately $100 \%$ within $72 \mathrm{~h}$. This gave a final glucose concentration of $9 \%(\mathrm{w} / \mathrm{v})$. Pretreated rice husk, reflecting the smaller scale evaluations, was not as effectively saccharified, reaching a plateau at much lower glucose concentrations after $>96 \mathrm{~h}$ of incubation.

The increasing interest in processes that involve high solids loadings to achieve higher product concentrations relates to the lower capital costs due to the requirements for smaller volume or fewer reactors, lower energy consumption for the reactions, and a reduction in water waste disposal costs [29]. Liu et al. [30], for example, reported laboratory (small scale $250 \mathrm{~mL}$ ) studies on batch-fed saccharification of sugarcane bagasse, and achieved $135 \mathrm{~g} / \mathrm{L}$ glucose $(13 \% \mathrm{w} / \mathrm{v})$ using cellulase loadings of $8.5 \mathrm{FPU} / \mathrm{g}$ substrate. Their pretreatment required high levels of hot alkali (equivalent to $200 \mathrm{~kg} \mathrm{NaOH}$ per tonne bagasse). An earlier report by Yang et al. [31] likewise achieved $175 \mathrm{~g} / \mathrm{L}$ glucose from batch addition of pretreated corn stover in the presence of cellulase loadings of $20 \mathrm{FPU} / \mathrm{g}$ substrate. Their pretreatment involved extensive peroxide and alkali treatments. The advantage of such pretreatments is that they extract much of the lignin, and produce substrates containing over $60 \%(\mathrm{w} / \mathrm{w})$ cellulose. The outweighing disadvantage, however, is that industrial exploitation would lead to a high level of salt pollution from the alkali used. In this study, we have used steam explosion, without 
the addition of other chemicals as a pretreatment, and a high torque bioreactor to handle a high solids loading with low enzyme levels (6 FPU/g substrate for rice straw, $10 \mathrm{FPU} / \mathrm{g}$ substrate for rice husk) to produce a high glucose yield, with potential for increasing it further through batch addition [22]. We have also definitively demonstrated that rice husk is much more difficult to saccharify than straw, directly impacting ethanol yield during simultaneous saccharification and fermentation.

\section{Conclusions}

The aim of this study has been to systematically compare the effects of uncatalysed steam explosion on the enzymatic saccharification and simultaneous saccharification and fermentation of rice straw and husk produced from the single variety, widely grown in Vietnam $(O$. sativa, cv. KhangDan18). In spite of having similar carbohydrate compositions, rice husk is much less amenable to saccharification even at optimal pretreatments when compared with rice straw. The limits to saccharification posed by rice husk cannot be solved by increases in cellulase or hemicellulase abundance. This result, combined with those from other studies using various pretreatments, suggest that the utilisation of rice husk as a biorefinery feedstock would be difficult to achieve in its native form. However, rice husk is produced in vast tonnages and is thus a prime target for exploitation. Therefore, breeding strategies aimed to reduce the recalcitrance of this abundant material, and further developments in pretreatment technologies such as AFEX [32,33] would be appropriate.

\section{Additional file}

Additional file 1: Figure S1. \% yield of glucose released from (a) pretreated straw and (b) pretreated husk during enzyme hydrolysis over $96 \mathrm{~h}$ as modulated by increasing concentrations of Cellic ${ }^{\circledR} \mathrm{HTec} 2 \mathrm{C} \% ; 5 \%$; $10 \% ; 15 \%$ : Cellic ${ }^{\circledR}$ HTec 2 concentration (\% g/g Cellic ${ }^{\circledR}$ CTec2)]. Samples were digested whilst being agitated at a substrate concentration of $5 \%$ (w/v) at $50^{\circ} \mathrm{C}$ for $96 \mathrm{~h}$ in cellulase (Cellic ${ }^{\circledR} \mathrm{CTec} 2$; between 0 and circa 22 $\mathrm{FPU} / \mathrm{g}$ cellulose).

\section{Abbreviations}

DM: dry matter; FPU: filter paper units; SSF: simultaneous saccharification and fermentation.

\section{Authors' contributions}

KWW conceived of the study and with IPW and SRAC designed the experimental programme. KWW, with help from GKM and IPW coordinated the study. H-GC and LT harvested and transported the rice straw and rice husk, and with DRW carried out the controlled steam explosion studies and quantified recoveries. H-GC, LT, NC and IPW carried out the enzymolysis profiling and optimisation studies. H-GC, LT, NC, and AE carried out the simultaneous saccharification and fermentation experiments, and AE and SRAC analysed samples for ethanol by HPLC. LT and SRAC carried out the extraction and HPLC analysis of fermentation inhibitors. H-GC, LT, PR and DRW developed and carried out the large-scale saccharification time courses using the high torque bioreactor. H-GC carried out an in-depth literature review. IPW, LT, GKM and
KWW drafted the manuscript; KWW revised the manuscript. All authors read and approved the final manuscript.

\section{Author details}

${ }^{1}$ The Biorefinery Centre, Institute of Food Research, Norwich Research Park, Colney, Norwich NR4 7UA, UK. ${ }^{2}$ Vietnam Academy of Agricultural Science, Hanoi, Vietnam. ${ }^{3}$ The Earlham Institute, Norwich Research Park, Norwich NR4 7UG, UK.

\section{Acknowledgements}

The authors wish to acknowledge Professor Simon McQueen-Mason, University of York, for overall leadership of the BBSRC International Scientific Interchange Scheme grant from which this study was conceived. The authors also gratefully acknowledge the provision of enzymes used in this study by Novozymes Ltd and yeast strain provided by the National Collection of Yeast Cultures (NCYC, UK).

\section{Competing interests}

The authors declare that they have no competing interests.

\section{Funding}

We thank the BBSRC for funding (BB/J013838/1 and Institute Strategic Programme "Food and Health"BB/J004545/1).

Received: 11 May 2016 Accepted: 19 August 2016

Published online: 05 September 2016

\section{References}

1. Yu J, Zhang JB, He J, Liu ZD, Yu ZN. Combinations of mild physical or chemical pretreatment with biological pretreatment for enzymatic hydrolysis of rice hull. Bioresour Technol. 2009;100:903-8.

2. Organisation FaA. 2016. FAO Rice Market Monitor. p. 1.

3. Singh A, Tuteja S, Singh N, Bishnoi NR. Enhanced saccharification of rice straw and hull by microwave-alkali pretreatment and lignocellulolytic enzyme production. Bioresour Technol. 2011:102:1773-82.

4. Fernandez A, Davis SB, Wendt JOL, Cenni R, Young RS, Witten ML. Public health-particulate emission from biomass combustion. Nature. 2001;409:998-1098.

5. Bond TC, Doherty SJ, Fahey DW, Forster PM, Berntsen T, et al. Bounding the role of black carbon in the climate system: a scientific assessment. J Geophys Res Atmos. 2013;118:5380-552.

6. Alberto MCR, Wassmann R, Gummert M, Buresh RJ, Quilty JR, et al. Straw incorporated after mechanized harvesting of irrigated rice affects net emissions of $\mathrm{CH} 4$ and $\mathrm{CO} 2$ based on eddy covariance measurements. Field Crop Res. 2015;184:162-75.

7. Moniruzzaman M. Effect of steam explosion on the physicochemical properties and enzymatic saccharification of rice straw. Appl Biochem Biotechnol. 1996:59:283-97.

8. Moniruzzaman M. Saccharification and alcohol fermentation of steamexploded rice straw. Bioresour Technol. 1996:55:111-7.

9. Taniguchi M, Takahashi D, Watanabe D, Sakai K, Hoshino K, et al. Effect of steam explosion pretreatment on treatment with Pleurotus ostreatus for the enzymatic hydrolysis of rice straw. J Biosci Bioeng. 2010;110:449-52

10. Ibrahim MM, El-Zawawy WK, Abdel-Fattah YR, Soliman NA, Agblevor FA. Comparison of alkaline pulping with steam explosion for glucose production from rice straw. Carbohydr Polym. 2011:83:720-6.

11. Sindhu R, Binod P, Janu KU, Sukumaran RK, Pandey A. Organosolvent pretreatment and enzymatic hydrolysis of rice straw for the production of bioethanol. World J Microb Biot. 2012;28:473-83.

12. Jin SY, Chen HZ. Superfine grinding of steam-exploded rice straw and its enzymatic hydrolysis. Biochem Eng J. 2006:30:225-30.

13. Yanez R, Alonso JL, Parajo JC. Enzymatic saccharification of hydrogen peroxide-treated solids from hydrothermal processing of rice husks. Process Biochem. 2006:41:1244-52.

14. Banerjee S, Sen R, Pandey RA, Chakrabarti T, Satpute D, et al. Evaluation of wet air oxidation as a pretreatment strategy for bioethanol 
production from rice husk and process optimization. Biomass Bioenergy. 2009;33:1680-6.

15. Piñeros-Castro Y, Velasco GA, Proaños J, Cortes W, Ballesteros I. Producción de azúcares fermentables por hidrólisis enzimática de cascarilla de arroz pretratada mediante explosión con vapor. Revista ION. 2011;24:23-8.

16. Jeya M, Zhang YW, Kim IW, Lee JK. Enhanced saccharification of alkali-treated rice straw by cellulase from Trametes hirsuta and statistical optimization of hydrolysis conditions by RSM. Bioresour Technol. 2009;100:5155-61.

17. Singh A, Bajar S, Bishnoi NR. Enzymatic hydrolysis of microwave alkali pretreated rice husk for ethanol production by Scheffersomyces stipitis and their co-culture Saccharomyces cerevisiae. Fuel. 2014;116:699-702.

18. Waldron KW. Bioalcohol production: biochemical conversion of lignocelIulosic biomass. Boca Raton: Woodhead Publishing Ltd: CRC Press Ltd; 2010. p. 476.

19. Cabrera E, Munoz MJ, Martin R, Caro I, Curbelo C, Diaz AB. Alkaline and alkaline peroxide pretreatments at mild temperature to enhance enzymatic hydrolysis of rice hulls and straw. Bioresour Technol. 2014;167:1-7.

20. Saeman JF, Bubl JL, Harris EE. Quantitative saccharification of wood and cellulose. Ind Eng Chem. 1945;17:35-7.

21. Ghose TK. Measurement of cellulase activities. Pure Appl Chem. 1987;59:257-68

22. Elliston A, Collins SRA, Wilson DR, Roberts IN, Waldron KW. High concentrations of cellulosic ethanol achieved by fed batch semi simultaneous saccharification and fermentation of waste-paper. Bioresour Technol. 2013;134:117-26.

23. Wood IP, Elliston A, Ryden P, Bancroft I, Roberts IN, Waldron KW. Rapid quantification of reducing sugars in biomass hydrolysates: improving the speed and precision of the dinitrosalicylic acid assay. Biomass Bioenergy. 2012:44:117-21.
24. Abedinifar S, Karimi K, Khanahmadi M, Taherzadeh MJ. Ethanol production by Mucor indicus and Rhizopus oryzae from rice straw by separate hydrolysis and fermentation. Biomass Bioenergy. 2009;33:828-33.

25. Moradi F, Amiri H, Soleimanian-Zad S, Ehsani MR, Karimi K. Improvement of acetone, butanol and ethanol production from rice straw by acid and alkaline pretreatments. Fuel. 2013;112:8-13.

26. Merali Z, Ho JD, Collins SRA, Le Gall G, Elliston A, et al. Characterization of cell wall components of wheat straw following hydrothermal pretreatment and fractionation. Bioresour Technol. 2013:131:226-34.

27. Novozymes. 2015. Novozymes Cellic ${ }^{\circledR} \mathrm{CTec} 2$ and HTec2-enzymes for hydrolysis of lignocellulosic. http://bioenergy.novozymes.com/en/ cellulosic-ethanol/CellicCTec3/Documents/AS_2010-01668-03.pdf.

28. Elliston A, Collins SRA, Faulds CB, Roberts IN, Waldron KW. Biorefining of waste paper biomass: increasing the concentration of glucose by optimising enzymatic hydrolysis. Appl Biochem Biotechnol. 2014;172:3621-34

29. Zhang Y, Liu YY, Xu JL, Yuan ZH, Qi W, et al. High solid and low enzyme loading based saccharification of agricultural biomass. Bioresources. 2012;7:345-53

30. Liu YY, Xu JL, Zhang Y, Yuan ZH, Xie J. Optimization of high solids fedbatch saccharification of sugarcane bagasse based on system viscosity changes. J Biotechnol. 2015;211:5-9.

31. Yang $M H$, Li WL, Liu BB, Li Q, Xing JM. High-concentration sugars production from corn stover based on combined pretreatments and fed-batch process. Bioresour Technol. 2010;101:4884-8.

32. Harun S, Balan V, Takriff MS, Hassan O, Jahim J, Dale BE. Performance of AFEX (TM) pretreated rice straw as source of fermentable sugars: the influence of particle size. Biotechnol Biofuels. 2013;6:40.

33. Kim SB, Lee $S J$, Lee JH, Jung YR, Thapa LP, et al. Pretreatment of rice straw with combined process using dilute sulfuric acid and aqueous ammonia. Biotechnol Biofuels. 2013:6:109.

\section{Submit your next manuscript to BioMed Central and we will help you at every step:}

- We accept pre-submission inquiries

- Our selector tool helps you to find the most relevant journal

- We provide round the clock customer support

- Convenient online submission

- Thorough peer review

- Inclusion in PubMed and all major indexing services

- Maximum visibility for your research

Submit your manuscript at www.biomedcentral.com/submit
O Biomed Central 